\title{
Vastuullisuudella kilpailuetua suomalaiselle elintarvikeketjulle?
}

\author{
Jaana Kotro ${ }^{1)}$, Lotta Jalkanen ${ }^{2}$ \\ 1) MTT, Latokartanonkaari 9,00790 Helsinki,jaana.kotro@mtt.fi \\ 2)MTT, Latokartanonkaari 9,00790 Helsinki, lotta.jalkanen@mtt.fi
}

\section{Tiivistelmä}

Suomalaisen ruokaketjun toiminta on monessa suhteessa esimerkillisen hyvällä tasolla, mutta sen toimintaan liittyviä lisäarvotekijöitä ei ole hyödynnetty liiketoiminnassa vielä systemaattisesti. Suomalaisen elintarvikeketjun vahvuuksien määrittely ja niistä viestiminen kuluttajille voidaan nähdä yhtenä keinona koko elintarvikeketjun lisäarvon luomiseen ja kansallisen kilpailukyvyn kehittämiseen.

MTT:n Lisäarvoa laatutyöstä -hankkeessa tunnistettiin suomalaiseen ruuantuotantoon liittyviä hyviä käytäntöjä ja lisäarvotekijöitä. Hankkeessa kerättiin aineistoa kirjallisuusselvitysten, kuluttajien ryhmäkeskustelujen, ruokaketjun toimija- ja sidosryhmähaastattelujen, asiantuntijatyöryhmäpalaverien ja keskustelutilaisuuksien avulla. Lisäksi hankkeessa tehtiin kaksi nettikyselyä, joihin vastasi 559 ruokaketjun toimijaa ja 1623 kuluttajaa.

Lisäarvotekijöitä tarkasteltiin vastuullisuuden seitsemän ulottuvuuden - tuoteturvallisuus, eläinten hyvinvointi, ravitsemus, ympäristövastuullisuus, työhyvinvointi, paikallisuus ja taloudellinen vastuu - kautta. Jokaisen vastuullisuusulottuvuuden osalta määriteltiin ulottuvuuden toteutumisen kannalta oleelliset osa-alueet. Osa-alueille tunnistettiin ruokaketjun toiminnassa tehtäviä toimintoja, jotka edistävät ulottuvuuden toteutumista ja joiden hyvä taso tuottaa suomalaiselle ruokaketjulle lisäarvoa.

Esimerkkeinä näistä lisäarvotekijöistä voidaan tuoteturvallisuuden osalta mainita jäljitettävyys, salmonellattomuus ja lääkejäämien vähäisyys, eläinten hyvinvoinnin osalta hormonittomuus sekä vapaus vaarallisista eläintaudeista. Ravitsemuksen näkökulmasta lisäarvotekijöiksi tunnistettiin ravitsemusinformaation monipuolisuus ja kuluttajien mahdollisuus tehdä valintoja ravitsemusnäkökulmasta, ympäristön osalta energiatehokkuuden kohentaminen sekä ympäristövaikutusten tavoitteellinen vähentäminen. Työhyvinvointi-ulottuvuuden lisäarvotekijäksi tunnistettiin työhyvinvointia edistävien ja ylläpitävien työkalujen ja käytäntöjen, kuten lomituspalveluiden, riskienhallintatyökalujen ja työaikajoustojen kehittäminen ja hyödyntäminen. Taloudellinen vastuu ja paikallisuus todettiin nivoutuvan voimakkaasti yhteen. Paikallinen ruuantuotanto sekä paikallisten tuotteiden ja raaka-aineiden käyttö tukee paikallista työllisyyttä ja aluetaloutta sekä ylläpitää paikallisia ruokakulttuureita.

Ruokaketjun toimintaan liittyy runsaasti toimintoja, joista suomalainen ruokaketju voi olla ylpeä, mutta joita ei ole viestitty kuluttajille. Lisäarvoa laatutyöstä -hankkeessa tehdyn kuluttajakyselyn mukaan $63 \%$ vastaajista ei saa mielestään riittävästi tietoa ruokaketjun toiminnasta. Tietoa kaivattiin erityisesti hinnanmuodostuksesta tuotantoketjun eri vaiheissa, tuoteturvallisuudesta, alkuperästä ja eläinten hyvinvointiin liittyvistä asioista. Hankkeen johtopäätöksenä todettiin, että avaamalla ruokaketjun toimintaa läpinäkyvämmäksi ja nostamalla ruokaketjussa tapahtuvaa työtä paremmin kuluttajien tietoisuuteen voitaisiin vahvistaa arvostusta ja ylläpitää luottamusta ruokaketjun toimintaa kohtaan ja vaikuttaa näin kuluttajien maksuhalukkuuteen. Tämä edellyttää konseptia, jolla ohjeistetaan ja varmistetaan vastuullisten toimintatapojen toteutuminen ja jäljittäminen ruokaketjun eri osissa sekä kuluttajalähtöisiä viestintämenetelmiä.

Vuosina 2008-2010 toteutettua Lisäarvoa laatutyöstä -hanketta rahoitti maa- ja metsätalousministeriön Laatuketju. Keskeisimmät yritysyhteistyökumppanit olivat HK Ruokatalo Oy ja Atria Suomi Oy.

Asiasanat: kilpailuetu, lisäarvo, vastuullisuus, ruokaketju 


\section{Johdanto}

Suomalaisen ruokaketjun toiminta on monessa suhteessa esimerkillisen hyvällä tasolla, mutta toimintaan liittyviä lisäarvotekijöitä ei ole hyödynnetty liiketoiminnassa vielä systemaattisesti. Jotta tätä laatutyötä voidaan hyödyntää, tulee pystyä vastamaan seuraaviin kysymyksiin: Mitkä ovat ne tekijät, joista suomalainen elintarvikeketju voi olla erityisen ylpeä? Mitä kuluttajat haluaisivat tietää ruokaketjun toiminnasta? Mistä muodostuu kotimaisen ruuantuotannon erityislaatu? Voitaisiinko kotimaisen ruuan arvostusta ja maksuhalukkuutta nostaa tarjoamalla kuluttajille heitä kiinnostavaa tietoa kotimaisen ruokaketjun toiminnasta. Vastauksia edellä esitettyihin kysymyksiin haettiin MTT:n Lisäarvoa laatutyöstä -hankkeessa (2008-2010).

\section{Suomalaisen elintarvikeketjun lisäarvotekijöitä}

Lisäarvoa laatutyöstä -hankkeessa tunnistettiin suomalaiseen ruuantuotantoon liittyviä hyviä käytäntöjä ja lisäarvotekijöitä. Hankkeessa kerättiin aineistoa kirjallisuusselvitysten, kuluttajien ryhmäkeskustelujen, ruokaketjun toimija- ja sidosryhmähaastattelujen, asiantuntijatyöryhmäpalaverien ja keskustelutilaisuuksien avulla. Lisäksi hankkeessa tehtiin kaksi nettikyselyä, joihin vastasi 559 ruokaketjun toimijaa ja 1623 kuluttajaa.

Lisäarvotekijöitä tarkasteltiin vastuullisuuden seitsemän ulottuvuuden - tuoteturvallisuus, eläinten hyvinvointi, ravitsemus, ympäristövastuullisuus, työhyvinvointi, paikallisuus ja taloudellinen vastuu (Forsman-Hugg ym. 2009) - kautta. Jokaisen vastuullisuusulottuvuuden osalta määriteltiin ulottuvuuden toteutumisen kannalta oleelliset toiminnot, jotka edistävät ulottuvuuden toteutumista. Lisäksi osa-alueille tunnistettiin ruokaketjun toiminnassa toteutuvia toimintoja, jotka edistävät ulottuvuuden toteutumista ja joiden hyvä taso tuottaa suomalaiselle ruokaketjulle lisäarvoa (kuva 1). Esimerkkeinä näistä lisäarvotekijöistä voidaan tuoteturvallisuuden osalta mainita jäljitettävyys, salmonellattomuus ja lääkejäämien vähäisyys, eläinten hyvinvoinnin osalta hormonittomuus sekä vapaus vaarallisista eläintaudeista. Ravitsemuksen näkökulmasta lisäarvotekijöiksi tunnistettiin ravitsemusinformaation monipuolisuus ja kuluttajien mahdollisuus tehdä valintoja ravitsemusnäkökulmasta, ympäristön osalta energiatehokkuuden kohentaminen sekä ympäristövaikutusten tavoitteellinen vähentäminen. Työhyvinvointiulottuvuuden lisäarvotekijäksi tunnistettiin työhyvinvointia edistävien ja ylläpitävien työkalujen ja käytäntöjen, kuten lomituspalveluiden, riskienhallintatyökalujen ja työaikajoustojen kehittäminen ja hyödyntäminen. Taloudellinen vastuu ja paikallisuus todettiin nivoutuvan voimakkaasti yhteen. Paikallinen ruuantuotanto sekä paikallisten tuotteiden ja raaka-aineiden käytön todettiin tukevan paikallista työllisyyttä ja aluetaloutta sekä ylläpitävän paikallisia ruokakulttuureita. (Kotro ym. 2011.) 


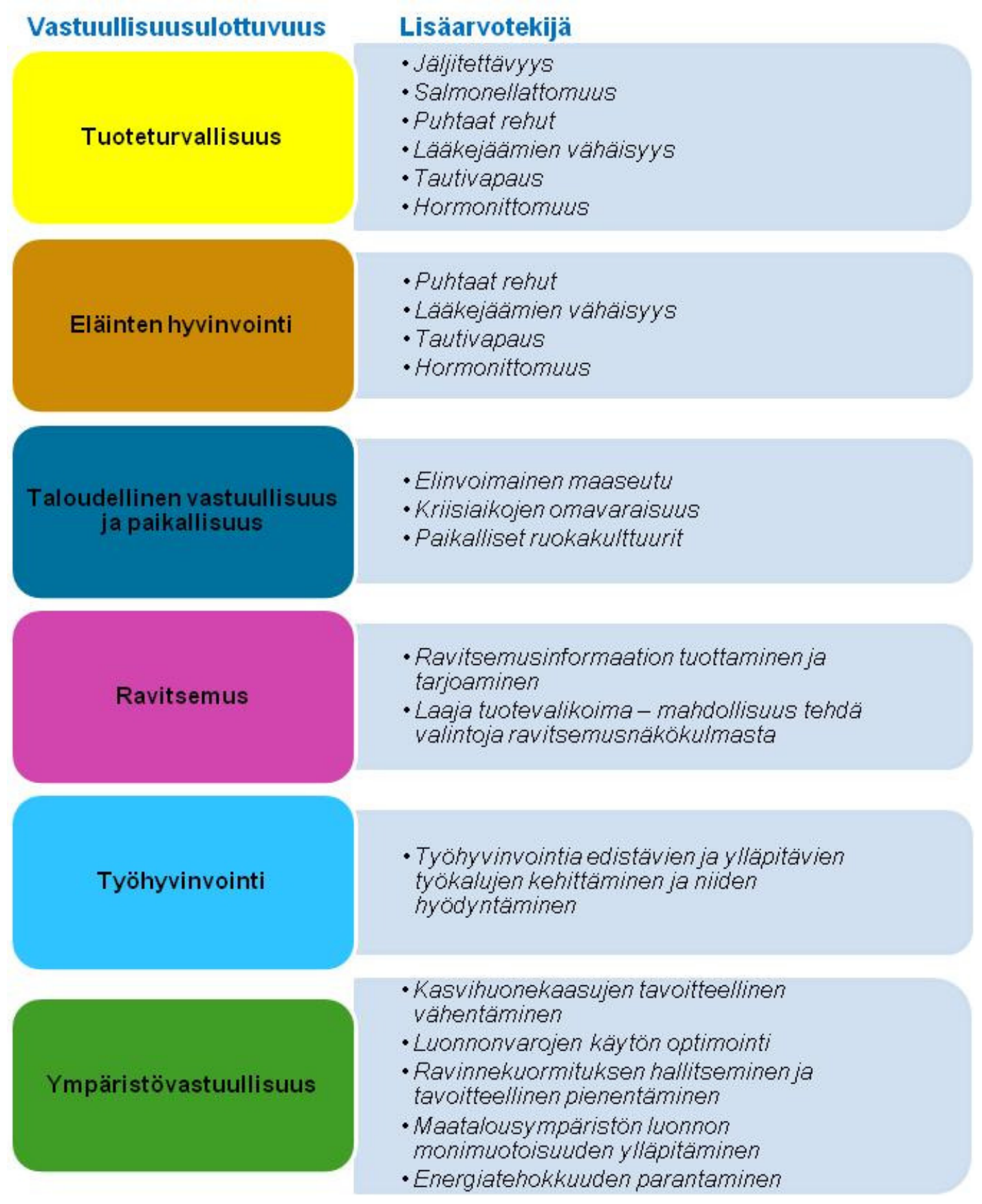

Kuva 1. Suomalaisen ruokaketjun lisäarvotekijöitä

\section{Vastuullisuus, kilpailukyky ja maksuvalmius}

Ruokaketjun toimijoille suunnatun kyselyn ( $\mathrm{N}=559)$ mukaan kuluttajien luottamuksen säilyttämisellä ja toiminnan vastuullisuudella on tulevaisuudessa suuri liiketoiminnallinen merkitys. Tätä tukevat myös kansainväliset tutkimukset, joiden mukaan toiminnan vastuullisuutta todentavilla ja siitä viestivillä järjestelmillä voidaan parantaa ruokaketjun kilpailukykyä.

Useiden tutkimusten mukaan kuluttajat ovat kiinnostuneita ja valmiita maksamaan lisähintaa tarkemmalla eläinten hyvinvointi, tuoteturvallisuus- ja ympäristötiedolla varustetuista elintarvikkeista (esim. Napolitano ym. 2007; Napolitano ym. 2010; Kehagia ym. 2007; Meuwissen ym. 2007; Mariá 2006; Gianni ja Colantuoni 2010), vaikkakin lisähinta, joka ollaan valmiita maksamaan, vaihtelee tutkimusten välillä maasta, tutkimuksen kohteesta ja tutkimusmenetelmästä riippuen. Oleellista kuitenkin oli, että tieto, jonka avulla kuluttajien maksuhalukkuutta pyrittiin kasvattamaan, oli todennettu (Dickensson ym. 2003). 
Lisäarvoa laatutyöstä -hankkeessa suomalaisten kuluttajien maksuhalukkuutta lähestyttiin eläinten hyvinvoinnin osalta. Kuluttajakyselyn ( $=1623)$ mukaan yli puolet kuluttajista olisi valmiita maksamaan lisähintaa eläinten hyvinvoinnin lisäämisestä. Lisäksi $2 / 3$ kuluttajista haluaisi varmistua tuotemerkinnän avulla, että tuotantoeläintä on kohdeltu hyvin. Vain vajaa 1/3 kuluttajista puolestaan oli sitä mieltä, että hinta on tärkeämpi kuin muut tekijät elintarvikkeita ostettaessa.

\section{Johtopäätökset}

Suomalaisessa ruokaketjussa tehtävä laadukas työ voidaan nähdä toistaiseksi vielä hyödyntämättömänä kilpailutekijänä. Lisäarvoa laatutyöstä -hankkeessa ruokaketjun toiminnasta tunnistettiin runsaasti toimintoja, joista suomalainen ruokaketju voi olla ylpeä, mutta joita ei ole viestitty kuluttajille. Samaan aikaan kuluttajista enemmistö kokee, ettei saa riittävästi tietoa ruokaketjun toiminnasta, kuten esimerkiksi hinnanmuodostuksesta tuotantoketjun eri vaiheissa, tuoteturvallisuudesta, alkuperästä ja eläinten hyvinvointiin liittyvistä asioista. Kuluttajien tiedontarpeiden tyydyttäminen ja luottamuksen vahvistaminen edellyttää läpinäkyvää ja vuorovaikutteista ruokajärjestelmää, jonka toiminta voidaan luotettavalla tavalla todentaa. Keinona vahvistaa kuluttajien arvostusta ja ylläpitää luottamusta ruokaketjun toimintaa kohtaan voisi olla ruokaketjun toiminnan tekeminen läpinäkyvämmäksi ja nostamalla näin ruokaketjussa tapahtuvaa työtä paremmin kuluttajien tietoisuuteen. Tämä edellyttää konseptia, jolla ohjeistetaan ja varmistetaan vastuullisten toimintatapojen toteutuminen ja jäljittäminen ruokaketjun eri osissa sekä kuluttajalähtöisiä viestintämenetelmiä. Vastuullisuuden kehittämiseen ja todentamiseen perustuvan kilpailustrategian toteutumiseksi tarvitaan lisäksi kuluttajalähtöisyyttä sekä ruokaketjun toimijoiden ja julkisen sektorin yhteistä päätöstä lähteä toteuttamaan koko ruokaketjun kattavaa toimintaa todentavaa ja viestivää järjestelmää.

Vuosina 2008-2010 toteutettua Lisäarvoa laatutyöstä -hanketta rahoitti maa-ja metsätalousministeriön Laatuketju. Keskeisimmät yritysyhteistyökumppanit olivat HK Ruokatalo Oy ja Atria Suomi Oy. Vastuullisuuden jäljitettävyysjärjestelmän suunnittelu jatkuu MTT:n koordinoimassa Vastuullisuuden jäljitettävyys -hankkeessa, jossa rahoittajina ovat mmm Laatuketju sekä edellä mainitut liha-alan yritykset.

\section{Kirjallisuus}

Forsman-Hugg, S., Katajajuuri, J, H., Paananen, J., Pesonen, I., Järvelä. \& Mäkelä, J. 2009. Elintarvikeketjun vastuullisuus. Kuvaus vuorovaikutteisen sisällön rakentamisen prosessista. Maa- ja elintarviketalous 140. Helsinki: MTT. 74 s.

Dickenson, D.,, Hobbs, J., \& Bailey, D. 2003. A Comparison of US and Canadian Consumers' Willingness To Pay for RedMeat Traceability. Paper prepared for presentation at the American Agricultural Economics Assosiation Annual Meating. Montreal, Canada July 27-30,2003.

Gianni, C. \& Colatuoni, F. 2010. Willingness to pay for traceable Meat attributes: a meta-analysis. International Journal on Food System. 3: 252-263.

Kehagia, O., Linardakis, M. \& Chryssochoidis, G. 2007. Beef traceability: Are Greek consumers willing to pay? Journal of Business. 2(2):173-190

Kotro, J., Jalkanen, L., Latvala, T., Kumpulainen, K., Järvinen M. \& Forsman-Hugg, S. 2011. Mistä suomalainen ruokaketju voi olla ylpeä? Näkemyksiä suomalaisen ruokaketjun lisäarvotekijöistä. MTT Kasvu 15. Tampereen Yliopistopaino Juvenes Print Oy. Tampere. 70 s.

Mariá, G, A. 2006. Public perception of farm animal welfare in Spain. Livestock Science. 103:250-256.

Napolitano, F., Girolami, A. \& Braghieri, A. 2010. Consumer liking and willingness to pay high welfare animal-based products. Food Science and Technology 21(11): 537-543.

Napolitano, F., Pacelli, C., Girolami, A. \& Braghieri, A. 2007. Effect of Information About Animal Welfare on Consumer Willingness to Pay for Yogurt. Journal of Daily Science. 91:910-917.

Meuwissen, M, P, M., Van Der Lans, I, A. \& Huire, R, B, M. 2007. Consumer preferences for pork supply chain attributes. NJAS. Wageningen Journal of Life Sciences 54 (3):293-312. 